Images in...

\title{
Chronic polyarthritis with diarrhoea, oedema and skin lesions
}

\author{
Shaifali Bansal, ${ }^{1}$ Sushil Jindal, ${ }^{1}$ Nitin Pandya, ${ }^{2}$ Kiran Pathak, ${ }^{3}$ Rakesh Biswas ${ }^{1}$ \\ ${ }^{1}$ Department of Medicine, People's College of Medical Sciences and Research Centre, Bhopal, India \\ ${ }^{2}$ Department of Dermatology, People's College of Medical Sciences and Research Centre, Bhopal, India \\ ${ }^{3}$ Department of Pathology, People's College of Medical Sciences and Research Centre, Bhopal, India
}

Correspondence to Rakesh Biswas, rakesh7biswas@gmail.com

\section{DESCRIPTION}

A 20-year-old man presented to our outpatient with a history of diarrhoea since the last 40 days. Stools were 3-4 times/day, watery and not containing mucous or blood. Patient had arthritis involving hips, knees and shoulders intermittently for 6 years which flared up again after his recent episodes of diarrhoea. He also observed skin lesions that were first noted on the scalp about 5 years ago and were now present on trunk, abdomen, thighs and soles since the last 3 months. Patient had recently also noted that he had puffiness around his eyes and swollen feet. He did not have any diagnosis or specific treatment in the past.

On physical examination, he appeared cachectic and had perorbital puffiness and pedal oedema. He had fixed flexion deformities in both knees (figure 1), along with restricted motion and swelling in both hips and right shoulder. He had skin lesions which were multiple, discrete to confluent well-defined scaly plaques with heaped up crusting present on the trunk and limbs (figures 2-4). There were

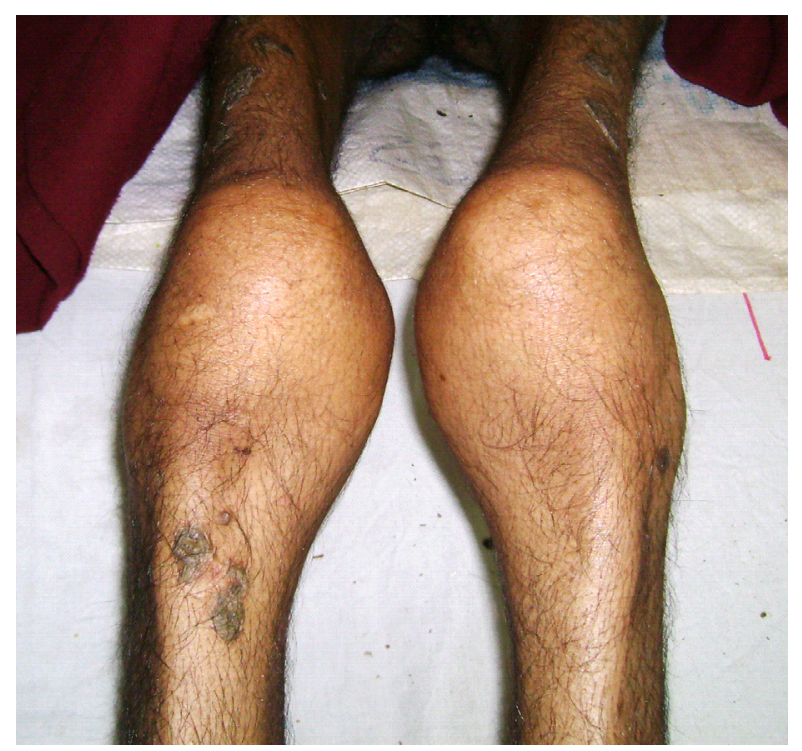

Figure 1 Fixed flexion deformities of both knees.

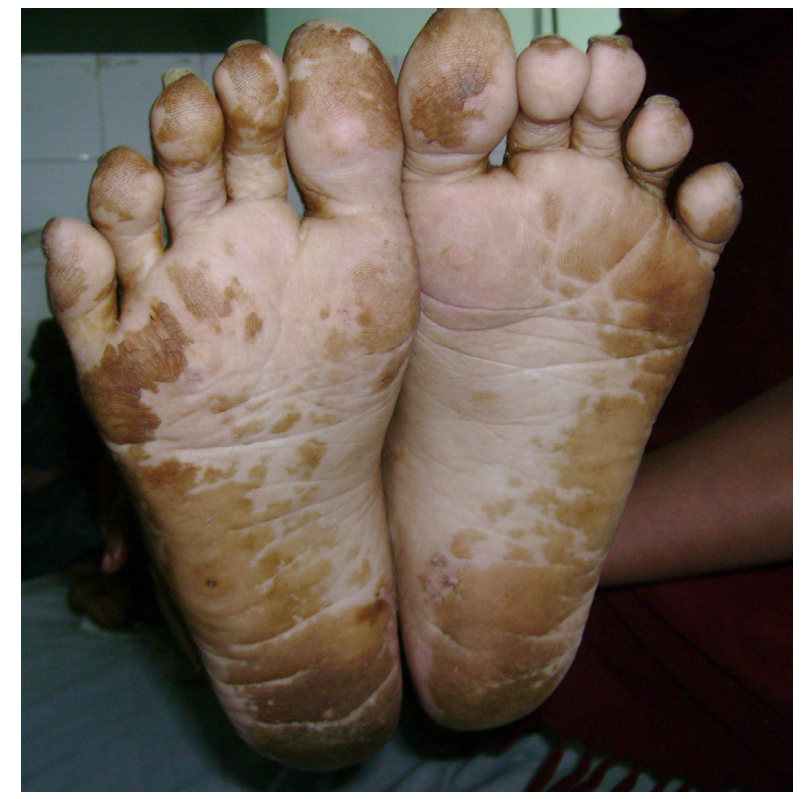

Figure 2 Keratoderma blenorrhagicum.

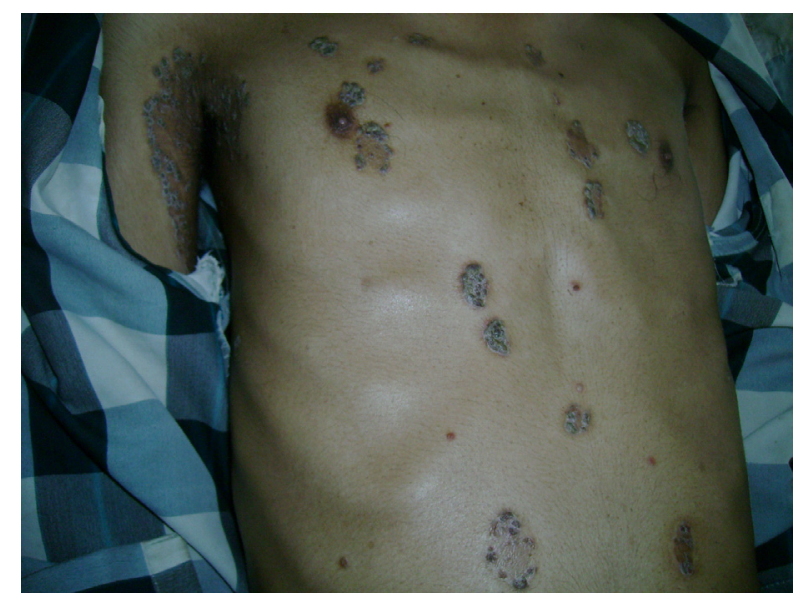

Figure 3 Skin lesion on trunk. 


\section{BMJ Case Reports}

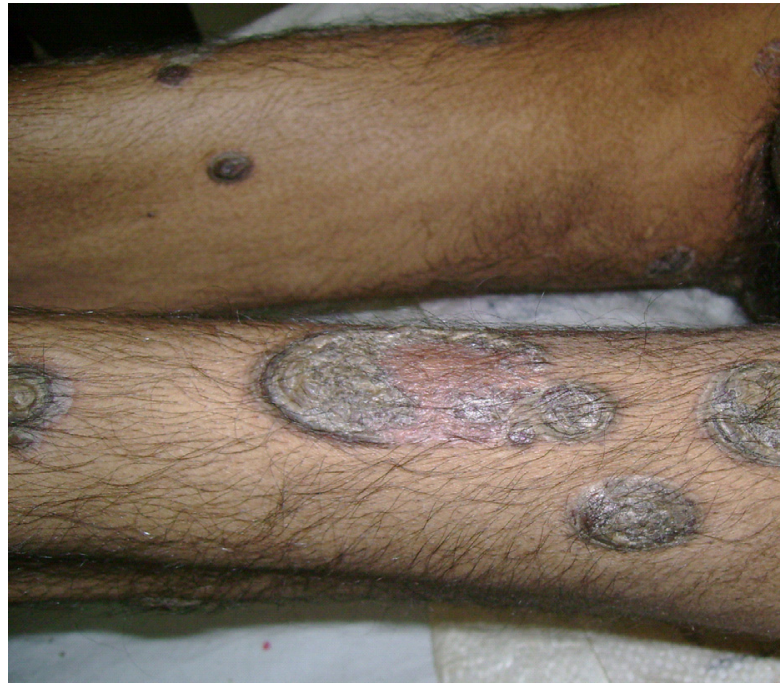

Figure 4 Skin lesion on limb.

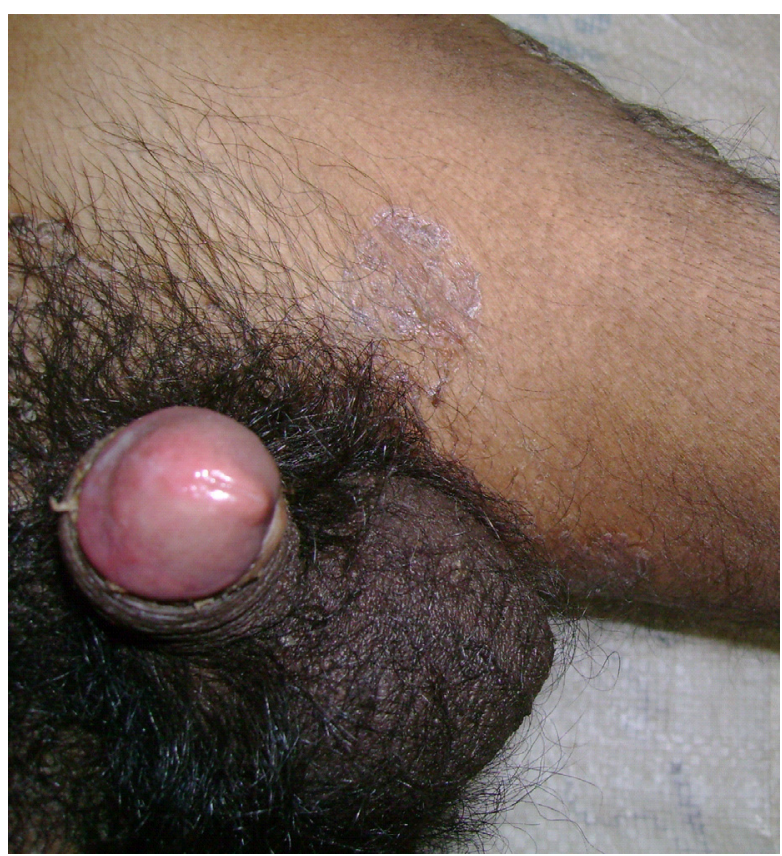

Figure 5 Circinate balanitis.

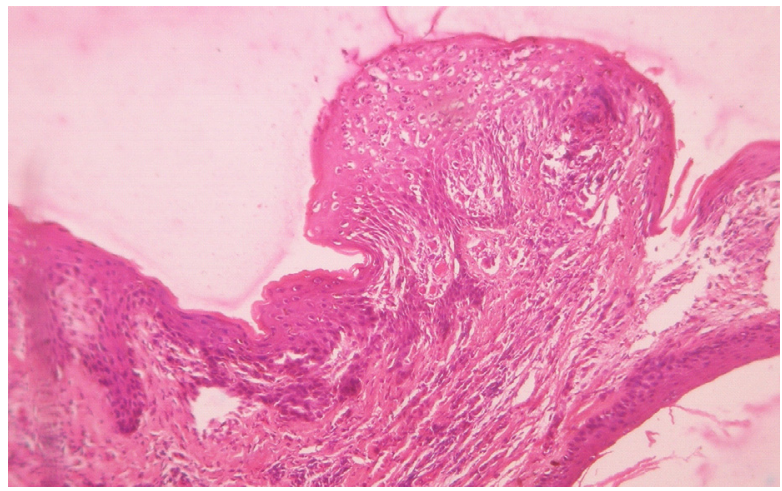

Figure 6 Acanthosis and elongation of rete ridges and diminution of granular layer.

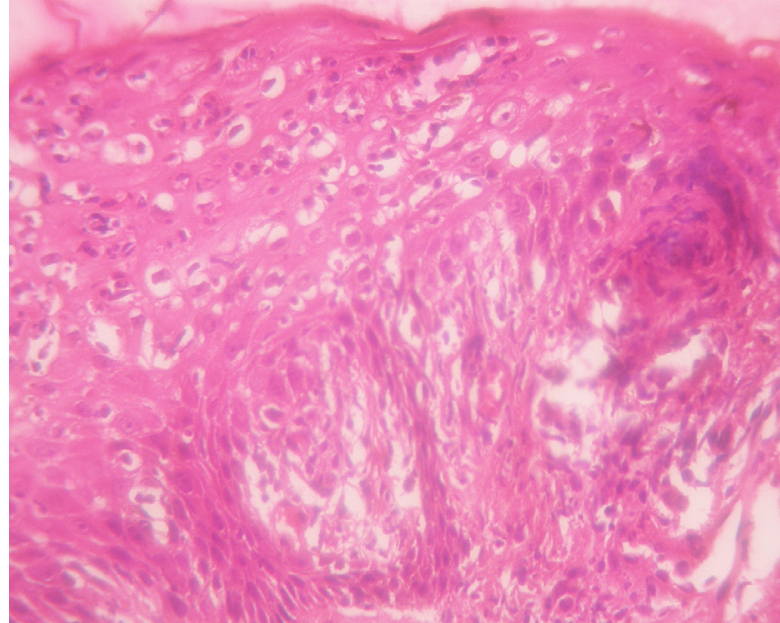

Figure 7 Spongioform pustule beneath the para keratotic cornified layer.

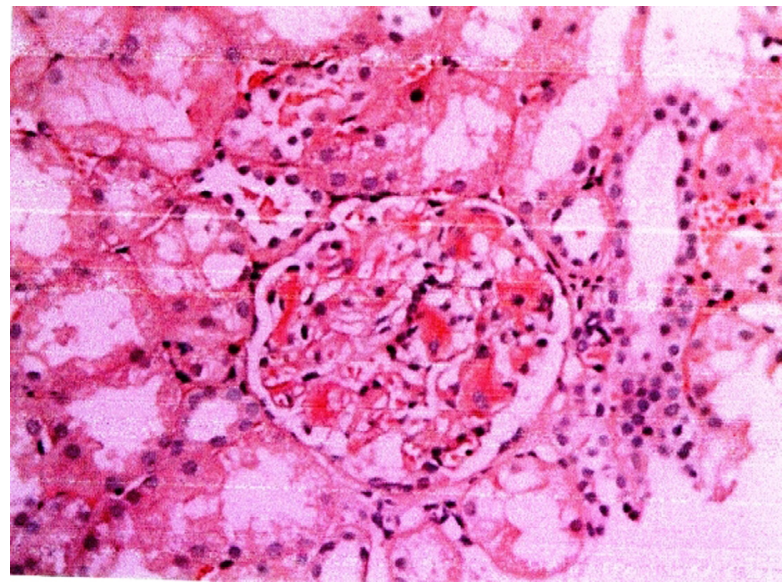

Figure 8 Renal biopsy suggestive of amyloidosis.

well-defined glazed erythematous patches present on the glans penis and prepuce in a circinate pattern (figure 5). Slit lamp examination of the eyes was normal.

His investigations revealed hypoalbuminemia (serum albumin $1.5 \mathrm{~g} / \mathrm{dl}$ ) $4+$ albuminuria and $5-6$ pus cells. USG abdomen showed enlarged kidneys and cystitis. On skin biopsy, histopathological findings were consistent with spongiform pustule of Reiter's disease (figures 6 and 7). Renal biopsy revealed positive congo red stain confirming amyloid involvement of kidney (figure 8). Patient was offered antibiotics imidazoles and quinolones in standard doses as well as antisecretory agents like racecadotril for diarrhoea. Non-steroidal anti-inflammatory drugs, methotrexate and physiotherapy for arthritis and symptomatic treatment for skin lesions. He gradually started improving. His skin lesions started regressing, his diarrhoea subsided and his joint pains started decreasing.

\section{DISCUSSION}

Our patient had predominant symptoms of severe deforming chronic polyarthritis with relatively recent onset of psoriasiform skin lesions that had a striking resemblance 
macroscopically and microscopically to keratoderma blenorrhagicum. Reactive arthritis previously termed Reiter's syndrome has a reported incidence of arthritis around $50-60 \%$ and keratoderma blenorrhagicum to the tune of $10 \% .^{1}$

Our patient didn't have any history of preceding urethritis but had pus cells in urine and ultrasound suggestive of cystitis that could suggest presence of urethral inflammation earlier and this is possibly consistent with the diagnostic criteria proposed for reactive arthritis. ${ }^{2}$

Our patient had nephrotic syndrome due to secondary amyloidosis that was again a result of the chronic inflammation associated with his arthritis. This association though rare has been reported earlier in the literature. ${ }^{3}$
Acknowledgements The authors would like to thank all caregivers of this patient.

\section{Competing interests None.}

Patient consent Obtained.

\section{REFERENCES}

1. Prakash S, Mehra NK, Bhargava S, et al. Reiter's disease in northern India. A clinical and immunogenetic study. Rheumatol Int 1983;3:101-4.

2. Kingsley G, Sieper J. Third International Workshop on Reactive Arthritis. 23-26 September 1995, Berlin, Germany. Report and abstracts. Ann Rheum Dis 1996;55:564-84

3. Sayal SK, Sanghi S, Prasad GK. Reiter's syndrome with secondary amyloidosis. Indian J Dermatol 2001;46:106-8.

This pdf has been created automatically from the final edited text and images.

Copyright 2010 BMJ Publishing Group. All rights reserved. For permission to reuse any of this content visit http://group.bmj.com/group/rights-licensing/permissions.

BMJ Case Report Fellows may re-use this article for personal use and teaching without any further permission.

Please cite this article as follows (you will need to access the article online to obtain the date of publication).

Bansal S, Jindal S, Pandya N, Pathak K, Biswas R. Chronic polyarthritis with diarrhoea, oedema and skin lesions. BMJ Case Reports 2010; 10.1136/bcr.12.2009.2595, date of publication

Become a Fellow of BMJ Case Reports today and you can:

- Submit as many cases as you like

- Enjoy fast sympathetic peer review and rapid publication of accepted articles

- Access all the published articles

- Re-use any of the published material for personal use and teaching without further permission

For information on Institutional Fellowships contact consortiasales@bmjgroup.com

Visit casereports.bmj.com for more articles like this and to become a Fellow 